\title{
FROM COMPILERS
}

2016 became anniversary for the "Problems of Literary Criticism" the scientific collection is 50. It is half-century of the interesting and dramatic Ukrainian Philological science, which was realized in the field of a radical break of the past social structure, the bifurcation point of which was the year 1991. Accordingly, the time of the publication of scientific collection split exactly in half: 25 Soviet years and 25 years of independent Ukraine.

The idea of compiling of bibliographic index of scientific publication, seemingly, no way had to reflect this dramatic effect, but obviously it's denied by the change of name, print run, publications content, priorities of singular research objects, specific posting of each publication, gradual change in editorial policy and a number of other. Bibliographic volume at the same time is presented as an interesting source of information and relevant historical evidence. Here is, for example, what was promised in Preface to the first issue (the scientific collection adhered to this trend actually till the end of the Soviet era):

Ukrainian republican interdepartmental collection "Issues of Russian Literature" starts to be published from 19663 issues per year, each of them has a volume of 10 printed pages. The collections will highlight the history and theory of Russian classical and Soviet literature, and also the history of literature and the university methods of teaching literature.

The specific character of literary studies, which are led in our republic, will be taken into consideration in regular publication of material on the Russian-Ukrainian literary interrelations.

The first issue of the collection is dedicated to Russian classical literature, the second - to Soviet literature, the third - to questions of literary theory and the mastery of Russian writers.

The collections of 1967 will be dedicated to the 50th anniversary of the Great October Socialist Revolution. The main focus will be on significance of October for the development of Russian literature, representation in literature of the October Revolution and the Civil War, works of Lenin about literature, the theory of socialist realism, and the Soviet literary progress in 50 years.

Since 1991, the scientific collection changes almost entirely its format, which was accentuated in the Preface of managing editor A. R. Volkov, which should be quoted almost entirely, because in terms 
of methodology the edition follows this program, because it doesn't lose its relevance even today:

The editorial staff aims to fill the "gaps" that exist in national literary periodical editions. In addition, we engage foreign scientists to cooperate with us.

The creation of self-reliant, independent Ukraine advances fundamentally new tasks for national science. Ukrainian science should get rid of the secondary, so to speak, peripherality, one-sided orientation toward Russian science. We seek to maintain scientific dialogue with the world on an equal footing. Unfortunately, today this equality hasn't been achieved yet.

Developing the traditions of academic science, "Problems of Literary Criticism" will pay main attention to theoretical aspects, general problems of historical and literary process, comparative study of literature, exploring these issues on material of the works of world literature. First of all it's supposed to make room to the fundamental articles of Ukrainian studies, but to those, which wouldn't isolate the literature of our nation from cultural whole, would consider it just in a global context. In particular, we want to represent the experience of international cooperation in the field of Slavonic Studies. Unfortunately, even in a zonal circle of Slavonic Studies the Ukrainian studies haven't occupied its appropriate place.

The editorial board, changing thematic range and the scientific conception of collection, seeks to create periodical printing organ, which would represent a wide range of ideas of literary criticism in Ukraine. In particular, we are committed to promote the further development of literary methodology. Trying to inspirit the theoretical thought, the editorial board will welcome the hypothesis articles, even such, with ideas of the authors of which they may not agree. Such articles will be published in the course of the discussions. The rise of the scientific discussion will contribute to further development of science.

In the next issues it is planned to highlight the question of teaching in higher institutes of education, methodical experience of the personnel of higher and secondary schools. The editorial board is also interested in reviews or specific articles, which would reflect the concepts of foreign literature studies, the rate of achievement of national scientific schools. It doesn't exclude the publishing of single researches on specific narrower questions. The modern science tends to complexity of research; therefore a special place has to be taken by articles from related scientific disciplines: study of folklore, mythology, translation studies etc.

The scientific publication changed its format several times during its existence, responding to professional requirements and capabilities of the appropriate time, but keeping the methodological basis. It's natural that editorial staff of the collection changed more than once in the half 
century. In historical retrospective review we will mention those, who were involved in its publishing history.

At the beginning the editorial board was led by Mikhailo Nazarok (executive editor from 1966 till 1979 p.), Olexander Pulynets (deputy editor), Anatoliy Volkov (executive secretary). In this first period the editorial board in different years included Lidia Berlovska (Odessa), Olga Bykova (Chernivtsi), Olexiy Vasylkivsky (Donetsk), Ivan Vyshnevskyi (Lviv), Vasyl Vorobyov (Kyiv), Isay Zaslavskyi (Kyiv), Volodymyr Kapustin (Kyiv), Mykola Kozlov (Uzhgorod), Vasyl Kuznetsov (Chernivtsi), Andriy Kulinych (Kyiv), Makar Lehavka (Kharkiv), Antonin Orishyn (Lviv), Kateryna Sitnikova (Dnipro). Over time they were joined by Mykhailo Homon (Kharkiv), Mykhailo Levchenko (Odessa), Volodymyr Malynkovskyi (Vinnytsia), Vitalyi Mosentsev (Kharkiv), Mykola Nikolayev (Chernivtsi), Vsevolod Pavlichenko (Simferopol), Volodymyr Popov (Lviv), Vira Rudenko (Odessa), Grygoriy Sinchenko (Chernivtsi), Evhen Tolstov (Uzhgorod), Viktor Udalov (Uzhgorod).

Starting with the issue 25 in 1975, the format of the collection changed from $70 \times 108 / 16$ to $60 \times 84 / 16$, correspondingly the cover design became different (the cover obtains its modern look since the issue 87 in 2013).

The editorial management of the collection in 1980 (issue 35) was taken by Mykola Nikolayev (executive editor till 1988), Ivan Vyshnevskyi (deputy editor), Dagmara Stepaniuk (executive secretary). There are new members of the editorial board: Ivan Kruk (Kyiv), Gennadiy Ponomariov (Uzhgorod), Ivan Spivak (Chernivtsi).

Since the issue 46 (1985) the collection is being published with ISSN 0321-1215.

Since the issue 53 in 1989, Anatoly Volkov becomes executive editor (up to 2003). Under his leadership the staff of the editorial board is being gradually renewed. It includes Semen Abramovych (Chernivtsi), Vyacheslav Bryukhovetskyi (Kyiv), Boris Bunchuk (Chernivtsi), Mykhailo Hirshman (Donetsk), Roman Hrom'yak (Ternopil), Viktor Gusev (Dnipro), Ihor Dzeverin (Kyiv), Boris Ivaniuk (executive secretary from 1995 till 2000), Dmytro Zatons'kyi (Kyiv) Ihor Zvarych (executive secretary in 2002-2003., deputy editor in 2004), Viktor Zinchenko (Odessa), Volodymyr Kazarin (Simferopol), Olexander Mihiliov (Kharkiv), Emilia Morozova (Lviv), Dmytro Nalyvayko (Kyiv), Petro Rykhlo (Chernivtsi), Olha Chervinska (deputy editor in 2002-2003), Mykhailo Yatsenko (Kyiv). 
In 1993 under the initiative of A. Volkov the collection "Questions of Russian Literature" was renamed to "Problems of Literary Criticism". First - without saving the previous numbering, however in the issue 3 (60) in 1996 the double numbering is restored. Eventually, the unified through numbering is introduced - since the issue 71 (2006).

The years 1990 were the most difficult and dramatic in the history of the edition: the print run is drastically reduced (from the maximum number of 3700 of the issue 9 in 1968 to 100 copies), the periodicity is also lost (in 1992, 1994, 1999 and 2001 the collection wasn't published). Despite this, scientific authority and status of the collection increases, since the issue 61 in 1997 it begins to be published jointly with the T. H. Shevchenko Institute of Literature of the National Academy of Sciences of Ukraine.

In 2002 the collection "Problems of Literary Criticism" was approved by Higher Attestation Commission as a special edition (The bulletin of Higher Attestation Commission of Ukraine. - № 3. - 2002. - P. 12).

Since the issue 53 in 2004 Olha Chervinska becomes the editor-inchief of the collection, the deputy editor-in-chief - Petro Rykhlo (executive secretary in 2005-2012), the executive secretary - Roman Dzyk (since 2013). The previous editorial board undergoes some changes: there join Nataliya Vysotsky (Kyiv), Tamara Hundorova (Kyiv), Olexander Keba (Kamianets-Podilskyi), Nataliya Kostenko (Kyiv), Anna Merezhinsky (Kyiv), Boris Shalahinov (Kyiv).

In 2009 the collection has received the certificate of state registration of print media. (KB № 16266-4738 $\mathrm{P}$ of 31.12.2009).

In 2012 there was a re-registration of edition in Centre International de l'ISSN (Key title: Pitannâ literaturoznavstva; Abbreviated key title: Pitannâ literaturozn.) with assigning of ISSN 2306-2908.

The significant enhancing of the status of scientific journals was contributed by the replenishment of the editorial board with such authoritative foreign scientists, as Dmytro Bak (Russia), Aloiz Woldan (Austria), Leonid Heller (Switzerland), Roman Mnich (Poland), Ivo Pospishyl (Czech Republic), Valeriy Tyupa (Russia). From now on "Problems of Literary Criticism" is actively included in the international scientometric bases (Index Copernicus, Central and Eastern European Online Library, Google Scholar, ResearchBib, Polska Bibliografia Naukowa, Open Access Infrastructure for Research in Europe, Bielefeld Academic Search Engine, WorldCat, Directory of Research Joiunals Indexing). Eventually, since 2016 the scientific collection receives the 
certificate of state registration of print media already as a scientific journal.

Regarding the principles of compiling of Classified Catalogue.

With regard to the large number and variety of headings, formed in the collection in these 50 years, in the Index their number is being reduced to 28 thematic clusters. In each of these clusters the articles aren't placed chronologically, but by alphabetical order of authors' surnames. In cases where the article thematically fit for multiple headings, the compilers chose a priority one, without duplicating the article in the other ones.

For convenience the Classified catalogue is completed with Bibliographical entry of the issues for 1966-2015, with Index of names of the articles' authors and Index of names of research objects.

Chernivtsi, 2012-2016 